\title{
A Quantitative Analysis of Chromium and Zinc in Water and Raw Milk in Chittagong, Bangladesh
}

\author{
S. Akther ${ }^{1 *}$, S. M. S. Shahriar ${ }^{2}$, H. M. Zakir' ${ }^{2}$, M. K. Alam ${ }^{1}$ \\ ${ }^{1}$ Department of Food Processing and Engineering, Chittagong Veterinary and Animal Sciences \\ University, Khulshi, Chittagong-4225, Bangladesh \\ ${ }^{2}$ Department of Applied Chemistry and Chemical Engineering, Rajshahi University, Bangladesh
}

Received 28 August 2015, accepted in final revised form 12 October 2015

\begin{abstract}
The concentration of selected heavy metals (chromium and zinc) was detected and estimated in water and raw milk collected from Chittagong City of Bangladesh. A total of 25 water samples and 20 raw milk samples were collected from different farms situated in 10 locations of Chittagong, Bangladesh. Chromium content in water was obtained in the range from $0.2 \mu \mathrm{g} / \mathrm{L}$ to $13 \mu \mathrm{g} / \mathrm{L}$. The highest level of chromium content in water was 13.068 $\mu \mathrm{g} / \mathrm{L}$. The content of chromium in raw milk was obtained in the range from $2 \mu \mathrm{g} / \mathrm{L}$ to 17 $\mu \mathrm{g} / \mathrm{L}$. The highest level of chromium in milk was $17.062 \mu \mathrm{g} / \mathrm{L}$. Chromium concentrations in water and milk were below the maximum allowed limit. The concentration of zinc in water was in the range from $0.01 \mathrm{mg} / \mathrm{L}$ to $1 \mathrm{mg} / \mathrm{L}$. The highest level of zinc in water was 1.024 $\mathrm{mg} / \mathrm{L}$. The concentration of zinc in raw milk was in the range from $0.6 \mathrm{mg} / \mathrm{L}$ to $0.9 \mathrm{mg} / \mathrm{L}$. The highest concentration of zinc in water was $1.024 \mathrm{mg} / \mathrm{L}$ which is around the toxicological guidance value of zinc.
\end{abstract}

Keywords: Chromium; Zinc; Water; Milk.

C2016 JSR Publications. ISSN: 2070-0237 (Print); 2070-0245 (Online). All rights reserved. doi: http://dx.doi.org/10.3329/jsr.v8i1.24776 J. Sci. Res. 8 (1), 93-100 (2016)

\section{Introduction}

Chromium $(\mathrm{Cr})$ and zinc $(\mathrm{Zn})$ is a naturally occurring element found in food products of both plant and animal origins. These are regarded as essential trace element in humans and animals, taking part in various metabolic processes. $\mathrm{Cr}$ an essential element is usually present in food in the trivalent form; the hexavalent form of $\mathrm{Cr}$ is toxic and not normally found in food [1]. $\mathrm{Cr}(\mathrm{VI})$ has been reported to be toxic and carcinogenic to humans owing to its oxidizing potential and easy permeation of biological membranes [2]. In living organisms, $\mathrm{Cr}$ is present in the more stable trivalent state, and its essential biological

\footnotetext{
Corresponding author: shireen cvasu@yahoo.com
} 
activities are due to the complexes known as "biologically active Cr" (glucose tolerance factor or GTF) [3]. Cr is a component of enzymes which control glucose metabolism and synthesis of fatty acids and cholesterol, and its deficiency leads to severe impairment of glucose tolerance, which finally leads to diabetes and atherosclerotic disease [4]. Insufficiency of $\mathrm{Cr}$ is caused mainly by its insufficient supply with food products. The recommended daily intake proposed for $\mathrm{Cr}$ by the US RDA is $50-200 \mu \mathrm{g} /$ day for a $60-\mathrm{kg}$ person [5]. These levels are not usually reached in the industrialized countries where $\mathrm{Cr}$ deficiency is perhaps the principal trace element deficiency, particularly in people above the age of 35. As a result, it is referred to as geriatric nutrient [6]. According to literature data, daily $\mathrm{Cr}$ intake in European countries ranges from $22 \mu \mathrm{g}$ to $146 \mu \mathrm{g}$, but in most of them it is under $100 \mu \mathrm{g}$, and in the USA it is as low as 23 to $62 \mu \mathrm{g}$ [7]. On the other hand, $\mathrm{Zn}$ is a trace element that is essential for human health. $\mathrm{Zn}$ constitutes about $33 \mu \mathrm{g} / \mathrm{g}$ of an adult body mass and it is essential as a constituent of many enzymes involved in several physiological functions, such as protein synthesis and energy metabolism [8]. Too much $\mathrm{Zn}$ can still cause eminent health problems, such as stomach cramps, skin irritations, vomiting, nausea and anaemia. Zn can be a danger to unborn and newborn children. When their mothers have absorbed large concentrations of zinc the children may be exposed to it through blood or milk of their mothers. To assess the dietary intake of $\mathrm{Cr}$ and $\mathrm{Zn}$ with food it is necessary to know their content in different groups of food products. $\mathrm{Cr}$ and $\mathrm{Zn}$ contents in fruits, vegetables and dairy products are relatively low, but their consumption is high, which make their contribution to $\mathrm{Cr}$ and $\mathrm{Zn}$ intake significant [2]. However, scientifically reliable data on the $\mathrm{Cr}$ and $\mathrm{Zn}$ contents in different foods and agricultural products are still insufficient [9]. Water, milk and dairy products make an important contribution to the supply of $\mathrm{Cr}$ and $\mathrm{Zn}$ for the human diet. The aim of the present study is to determine the concentration of $\mathrm{Cr}$ and $\mathrm{Zn}$ in water and cow's milk available in market in Chittagong city corporation area of Bangladesh.

\section{Experimental}

\subsection{Sample collection}

Total 25 and 20 samples of water and raw milk were collected from 10 different locations during March-April, 2014 in Chittagong area of Bangladesh which are listed in Table 1.

\subsection{Sample preparation}

$\mathrm{HNO}_{3}$ was used for the dilution and mineralization of water samples. $100 \mathrm{~mL}$ of each representative water sample was transferred into Pyrex beaker containing $10 \mathrm{~mL}$ of conc. $\mathrm{HNO}_{3}$. The sample was boiled slowly and then evaporated on a hotplate to the lowest possible volume (about $20 \mathrm{~mL}$ ). The beaker was allowed to cool and another $5 \mathrm{~mL}$ of conc. $\mathrm{HNO}_{3}$ was added. Heating was continued with the addition of conc. $\mathrm{HNO}_{3}$ as necessary until digestion was complete. The sample was evaporated to dryness and then cooled, followed by the addition of $5 \mathrm{~mL} \mathrm{HCl}$ solution $(1: 1 \mathrm{v} / \mathrm{v})$. The solution was 
warmed and $5 \mathrm{~mL}$ of $5 \mathrm{M} \mathrm{NaOH}$ was added, and then filtered through Whatman No. 42 filter paper. The filtrate was transferred to $100 \mathrm{~mL}$ volumetric flask, diluted upto the mark with deionized water and then subjected to elemental analysis.

For the milk samples, $5 \mathrm{~mL}$ of milk was pipetted into the $200 \mathrm{~mL}$ cylindrical flask. Conc. $\mathrm{HNO}_{3}(10 \mathrm{~mL})$ and $\mathrm{H}_{2} \mathrm{SO}_{4}(3 \mathrm{~mL})$ as well as milk were heated at $120^{\circ} \mathrm{C}$ for $4 \mathrm{~h}$. After heating $1 \mathrm{~mL}$ of $20 \% \mathrm{H}_{2} \mathrm{O}_{2}$ was added and heated the mixture at $200^{\circ} \mathrm{C}$ for $8 \mathrm{~min}$. The final digested sample was diluted to $50 \mathrm{~mL}$ with deionized water and then filtered through Whatman No. 42 filter paper. The filtered solution was then used for the elemental analysis.

Table 1. Locations of sample collection.

\begin{tabular}{ccc}
\hline \multicolumn{2}{c}{ Sample Code } & Location \\
Water & Milk & Anwara \\
W-1 & M-1 & \\
W-2 & M-2 & Patiya Pourashava \\
W-3 & M-3 & \\
W-4 & M-4 & Hathazari \\
W-5 & M-5 & Raozan \\
W-6 & M-6 & \\
W-7 & M-7 & Sitakunda (north west) \\
W-8 & M-8 & \\
W-9 & M-9 & \\
W-10 & M-10 & \\
W-11 & M-11 & Mirsharai \\
W-12 & M-12 & \\
W-13 & & \\
W-14 & M-13 & \\
W-15 & M-14 & Halishohor \\
W-16 & & \\
W-17 & M-15 & \\
W-18 & M-16 & Bondor \\
W-19 & & \\
W-20 & M-17 & \\
W-21 & M-18 & EPZ \\
W-22 & W-23 & M-19 \\
W-24 & M-20 & \\
W-25 & & \\
& &
\end{tabular}

\subsection{Analytical methods and instrumentation}

$\mathrm{Cr}$ and $\mathrm{Zn}$ in water and milk samples were determined according to previously described methods [10,11]. The samples were analyzed in a laboratory with a quality assurance schemes by using "Analytikjena Atomic Absorption Spectrophotometer, model: ZEEnit700P, Germany”. 


\subsection{Measurement of different variables}

Exposure estimates have been compared with health-based toxicological reference values (e.g. heavy metals have been compared with acceptable daily intakes ADI).

\subsection{Data analysis}

The concentrations of $\mathrm{Cr}$ and $\mathrm{Zn}$ in water and raw milk were determined by using ASpect LS 1.2.0.0, Analytik Jena AG 2011-2012 system software. Statistical analysis was performed by using SPSS statistical software of version 14. All values were expressed as mean \pm standard deviation (SD).

\section{Results and Discussion}

Atomic absorption spectrophotometer (AAS) was calibrated with $\mathrm{Cr}$ concentrations at 5 ppb, $10 \mathrm{ppb}$, and $15 \mathrm{ppb}$ respectively for the calibration of the AAS. The AAS was also calibrated with $\mathrm{Zn}$ concentrations at $0.40 \mathrm{ppm}, 0.80 \mathrm{ppm}$, and $1.20 \mathrm{ppm}$ respectively. The results of water sample analyses are given in Table 2 . The content of $\mathrm{Cr}$ in water was obtained in the range from $0.2 \mu \mathrm{g} / \mathrm{L}$ to $13 \mu \mathrm{g} / \mathrm{L}$. The highest level of $\mathrm{Cr}$ in water was $13.068 \mu \mathrm{g} / \mathrm{L}$. Cr concentration in water was below the maximum allowed limit. The concentration of $\mathrm{Zn}$ in water was in the range from $0.01 \mathrm{mg} / \mathrm{L}$ to $1 \mathrm{mg} / \mathrm{L}$ with the highest concentration being observed was $1.024 \mathrm{mg} / \mathrm{L}$. The concentration of $\mathrm{Cr}$ and $\mathrm{Zn}$ in raw milk are given in Table 3 . The content of $\mathrm{Cr}$ in raw milk was obtained in the range from 2 $\mu \mathrm{g} / \mathrm{L}$ to $17 \mu \mathrm{g} / \mathrm{L}$. The highest level of $\mathrm{Cr}$ in milk was $17.062 \mu \mathrm{g} / \mathrm{L}$. The concentration of $\mathrm{Zn}$ in raw milk was in the range from $0.6 \mathrm{mg} / \mathrm{L}$ to $0.9 \mathrm{mg} / \mathrm{L}$ and the highest concentration was $0.984 \mathrm{mg} / \mathrm{L}$.

The maximum allowable limit of $\mathrm{Cr}$ in water according to United State Environmental Protection Agency (EPA) is $0.1 \mathrm{mg} / \mathrm{L}$ or $100 \mu \mathrm{g} / \mathrm{L}$ [12]. The Codex Alimentarius Committee considered the level of $\mathrm{Cr}$ is $0.05 \mathrm{mg} / \mathrm{L}$ or $50 \mu \mathrm{g} / \mathrm{L}$ for water and health-related certain substances [13]. The Secondary Maximum Contaminant Level of $\mathrm{Zn}$ in water according to United State Environmental Protection Agency (EPA) is $5 \mathrm{mg} / \mathrm{L}$ [12] and according to Codex Alimentarius the toxicological guidance value of $\mathrm{Zn}$ is $0.3-1$ $\mathrm{mg} / \mathrm{kg}$ body weight [14]. In this study, the Cr content in all the samples was found under maximum permeable limit. The maximum concentration of $\mathrm{Cr}$ in raw milk $(17.062 \mu \mathrm{g} / \mathrm{L})$ is below the safe limit for $\mathrm{Cr}$ in water and health-related certain substances. The highest concentration of $\mathrm{Zn}$ in water $(1.024 \mathrm{mg} / \mathrm{L})$ is around the toxicological guidance value of zinc.

In several countries, similar studies were previously reported concerning heavy metals as is the case in the current study. In surface waters in the USA, levels up to 84 $\mu \mathrm{g} / \mathrm{L}$ have been found [15]; in central Canada, surface water concentrations ranged from 0.2 to $44 \mu \mathrm{g} / \mathrm{L}$ (National Water Quality Data Bank (NAQUADAT), Inland Waters 
Directorate, Environment Canada, 1985). In the Rhine, Cr levels are below $10 \mu \mathrm{g} / \mathrm{L}$ [16], and in $50 \%$ of the natural stream waters in India the concentration is below $2 \mu \mathrm{g} / \mathrm{L}$ [17].

Table 2. Concentration of chromium and zinc in water

\begin{tabular}{|c|c|c|}
\hline \multirow[b]{2}{*}{ Sample no. } & \multicolumn{2}{|c|}{ Concentration in } \\
\hline & $\begin{array}{c}\mathrm{Cr}(\mu \mathrm{g} / \mathrm{L}) \\
(\text { mean } \pm \mathrm{SEM}) \\
\mathrm{n}=3\end{array}$ & $\begin{array}{c}\mathrm{Zn}(\mathrm{mg} / \mathrm{L}) \\
(\text { mean } \pm \mathrm{SEM}) \\
\mathrm{n}=3\end{array}$ \\
\hline $\mathrm{W}-1$ & $1.882 \pm 0.0003$ & $0.524 \pm 0.0015$ \\
\hline W-2 & $0.604 \pm 0.0050$ & $1.024 \pm 0.0013$ \\
\hline W-3 & $1.033 \pm 0.0008$ & $0.832 \pm 0.0007$ \\
\hline W-4 & $0.614 \pm 0.0008$ & ND \\
\hline W-5 & $0.512 \pm 0.0006$ & $0.442 \pm 0.0010$ \\
\hline W-6 & $1.098 \pm 0.0004$ & $0.015 \pm 0.0008$ \\
\hline W-7 & $2.112 \pm 0.0015$ & $0.016 \pm 0.0006$ \\
\hline W-8 & $4.232 \pm 0.0030$ & $0.826 \pm 0.0012$ \\
\hline W-9 & $0.947 \pm 0.0009$ & $0.429 \pm 0.0005$ \\
\hline $\mathrm{W}-10$ & $0.854 \pm 0.0012$ & ND \\
\hline $\mathrm{W}-11$ & $3.122 \pm 0.0012$ & $1.006 \pm 0.0006$ \\
\hline $\mathrm{W}-12$ & $1.342 \pm 0.0010$ & $0.085 \pm 0.0010$ \\
\hline $\mathrm{W}-13$ & $5.622 \pm 0.0022$ & ND \\
\hline W-14 & $8.245 \pm 0.0045$ & $0.634 \pm 0.0008$ \\
\hline $\mathrm{W}-15$ & $0.896 \pm 0.0028$ & $0.084 \pm 0.0012$ \\
\hline W-16 & ND & $0.224 \pm 0.0007$ \\
\hline $\mathrm{W}-17$ & $0.287 \pm 0.0017$ & $0.205 \pm 0.0005$ \\
\hline W-18 & $6.438 \pm 0.0060$ & $0.064 \pm 0.0004$ \\
\hline W-19 & $3.232 \pm 0.0017$ & $0.322 \pm 0.0007$ \\
\hline $\mathrm{W}-20$ & $0.697 \pm 0.0004$ & $0.084 \pm 0.0004$ \\
\hline $\mathrm{W}-21$ & $1.872 \pm 0.0033$ & ND \\
\hline $\mathrm{W}-22$ & $9.523 \pm 0.0086$ & $0.109 \pm 0.0006$ \\
\hline $\mathrm{W}-23$ & $13.068 \pm 0.0098$ & $0.566 \pm 0.0010$ \\
\hline $\mathrm{W}-24$ & ND & $0.342 \pm 0.0006$ \\
\hline $\mathrm{W}-25$ & $1.456 \pm 0.0015$ & $0.435 \pm 0.0008$ \\
\hline
\end{tabular}

In general, the $\mathrm{Cr}$ concentration in groundwater is low $(<1 \mu \mathrm{g} / \mathrm{L})$. In Netherland, a mean concentration of $0.7 \mu \mathrm{g} / \mathrm{L}$ has been measured, with a maximum of $5 \mu \mathrm{g} / \mathrm{L}$ [18]. In India, $50 \%$ of 1473 water samples from dug wells contained less than $2 \mu \mathrm{g} / \mathrm{L}$ [17]. In groundwater of the USA, levels up to $50 \mu \mathrm{g} / \mathrm{L}$ have been reported [15]; in shallow groundwater, median levels of $2-10 \mu \mathrm{gL}$ have been found [19]. Most supplies in the USA contain less than $5 \mu \mathrm{g} / \mathrm{L}$. In 1986, levels in 17 groundwater supplies and one surface water supply exceeded $50 \mu \mathrm{g} / \mathrm{L}$. Approximately $18 \%$ of the population of the USA are exposed to drinking-water levels between 2 and $60 \mu \mathrm{g} / \mathrm{L}$ and $<0.1 \%$ to levels between 60 and 120 $\mu \mathrm{g} / \mathrm{L}$ [15]. In Netherland, the Cr concentration in $76 \%$ of the supplies was below $1 \mu \mathrm{g} / \mathrm{L}$ and of $98 \%$ below $2 \mu \mathrm{g} / \mathrm{L}$ [20]. A survey of Canadian drinking-water supplies gave an overall median level of $\mathrm{Cr}$ as $2 \mu \mathrm{g} / \mathrm{L}$, with maxima of $14 \mu \mathrm{g} / \mathrm{L}$ (raw water) and $9 \mu \mathrm{g} / \mathrm{L}$ (treated water) [21]. Cocho et al. reported that normal cow milk contains 5-15 $\mu \mathrm{g} / \mathrm{L}$ of $\mathrm{Cr}$ [22]. 
In natural surface waters, the concentration of $\mathrm{Zn}$ is usually below $10 \mu \mathrm{g} / \mathrm{L}$, and in groundwaters, $10-40 \mu \mathrm{g} / \mathrm{L}$ [23]. In tap-water, the $\mathrm{Zn}$ concentration can be much higher as a result of the leaching of $\mathrm{Zn}$ from piping and fittings [24]. The most corrosive waters are those of low $\mathrm{pH}$, high carbon dioxide content, and low mineral salt content. In a Finnish survey, $67 \%$ of public water supplies, the median $\mathrm{Zn}$ content in water samples taken upstream and downstream of the waterworks was below $20 \mu \mathrm{g} / \mathrm{L}$; much higher concentrations were found in tap-water, the highest being $1.1 \mathrm{mg} / \mathrm{L}$ [25]. Even higher $\mathrm{Zn}$ concentrations (up to $24 \mathrm{mg} / \mathrm{L}$ ) were reported in a Finnish survey of water from almost 6000 wells [26].

Table 3. Concentration of $\mathrm{Cr}$ and $\mathrm{Zn}$ in raw milk.

\begin{tabular}{ccc}
\hline Sample no. & $\begin{array}{c}\mathrm{Cr}(\mu \mathrm{g} / \mathrm{L}) \\
(\mathrm{mean} \pm \mathrm{SEM}) \\
\mathrm{n}=3\end{array}$ & $\begin{array}{c}\text { Concentration }(\mathrm{mg} / \mathrm{L}) \\
(\text { mean } \pm \mathrm{SEM}) \\
\mathrm{n}=3\end{array}$ \\
\hline $\mathrm{M}-1$ & $6.016 \pm 0.0015$ & $0.984 \pm 0.0012$ \\
$\mathrm{M}-2$ & $5.014 \pm 0.0008$ & $0.826 \pm 0.0041$ \\
$\mathrm{M}-3$ & $4.625 \pm 0.0012$ & $\mathrm{ND}$ \\
$\mathrm{M}-4$ & $7.116 \pm 0.0023$ & $0.728 \pm 0.0022$ \\
$\mathrm{M}-5$ & $5.348 \pm 0.0022$ & $0.904 \pm 0.0034$ \\
$\mathrm{M}-6$ & $6.316 \pm 0.0010$ & $0.711 \pm 0.0016$ \\
$\mathrm{M}-7$ & $10.452 \pm 0.0011$ & $0.920 \pm 0.0052$ \\
$\mathrm{M}-8$ & $\mathrm{ND}$ & $0.684 \pm 0.0046$ \\
$\mathrm{M}-9$ & $8.254 \pm 0.0028$ & $\mathrm{ND}$ \\
$\mathrm{M}-10$ & $12.045 \pm 0.0016$ & $0.832 \pm 0.0058$ \\
$\mathrm{M}-11$ & $\mathrm{ND}$ & $0.801 \pm 0.0046$ \\
$\mathrm{M}-12$ & $2.854 \pm 0.0014$ & $0.588 \pm 0.0055$ \\
$\mathrm{M}-13$ & $8.482 \pm 0.0026$ & $0.942 \pm 0.0064$ \\
$\mathrm{M}-14$ & $11.624 \pm 0.0058$ & $0.785 \pm 0.0048$ \\
$\mathrm{M}-15$ & $5.033 \pm 0.0008$ & $\mathrm{ND}$ \\
$\mathrm{M}-16$ & $6.614 \pm 0.0008$ & $0.905 \pm 0.0082$ \\
$\mathrm{M}-17$ & $17.062 \pm 0.0086$ & $0.769 \pm 0.0085$ \\
$\mathrm{M}-18$ & $6.342 \pm 0.0048$ & $0.824 \pm 0.0050$ \\
$\mathrm{M}-19$ & $3.868 \pm 0.0082$ & $0.916 \pm 0.0085$ \\
$\mathrm{M}-20$ & $6.134 \pm 0.0030$ & $0.774 \pm 0.0065$ \\
\hline
\end{tabular}

$\mathrm{ND}=$ Not detectable

Zn concentrations in cow milk ranges from 2-6 mg/L [27]. Pechova et. al. reported that $\mathrm{Zn}$ level in cow milk is $3.855 \pm 0.814 \mathrm{mg} / \mathrm{L}$ [28]. Only a few studies on the content of $\mathrm{Zn}$ in cow milk have been published to date, and the factors affecting its concentration in milk have not been described thoroughly. Zinc in cow milk primarily binds to casein and, to a small extent, citrate. Almost $90 \%$ of $\mathrm{Zn}$ binds to casein in mature milk, in contrast to just $60 \%$ in the colostrums [29]. In casein, $\mathrm{Zn}$ binds primarily to colloid calcium phosphate of casein micelles [30]. 


\section{Conclusion}

The purpose of this study was to focus on concentration of selected metals in water and raw milk. In this study, it was found that in both water and raw milk concentrations of $\mathrm{Cr}$ and $\mathrm{Zn}$ were within the maximum limit. Comparative study of the present work with those of relevant works done in other countries revealed similar levels of metals in water and raw milk. Further studies are necessary to evaluate the contents of "essential" and "toxic" heavy metals on a greater number of samples to confirm the absence of possible toxicological risks.

\section{Acknowledgments}

The authors are thankful to the department of Applied Chemistry and Chemical Technology, Faculty of Food Science and Technology, Chittagong Veterinary and Animal Sciences University, Bangladesh and UGC (University Grant Comission) for financial support and necessary facilities.

\section{References}

1. L. Noel, J. -C Leblanc, and T. Guerin, Food Addit. Contam. 20, 44 (2003). http://dx.doi.org/10.1080/0265203021000031573

2. I. Schonsleben, M. Wilplinger, and W. Pfannhauser, in Determination of the Trace Element Chromium in Various Foodstuffs - Proc. Euro Food Chem. (Vienna, 1995) VIII, pp. 665-669.

3. R. A. Anderson, Total. Environ. 17, 13 (1981). http://dx.doi.org/10.1016/0048-9697(81)90104$\underline{2}$

4. R. Cornelis and B. Wallaeys, Chromium revisited, in: Trace Element Analytical Chemistry in Medicine and Biology, eds. P. Brätter et al. (Walter de Gruyter, Berlin, New York, 1984) 3, pp. 219-233.

5. Food and Nutrition Board, Committee on Dietary Allowances, Recommended Dietary Allowances, 1989, $10^{\text {th }}$ edition (Washington DC. National Academy Press, 1989).

6. C. J. Mateos, M. V. Aguillar, and M. C. Martinez-Papa, J. Agric. Food Chem. 51, 401 (2003). http://dx.doi.org/10.1021/jf025574x

7. R. V. Cauwenbergh, P. Hendrix, H. Robberecht, and H. Deelstra, Zeitschrift LebensmittelUntersuchung und Forschung 203, 203 (1996). http://dx.doi.org/10.1007/BF01192863

8. P. C. Onianwa, A. O. Adeyemo, O. E. Idowu, and E.E. Ogabiela, Food Chem. 72, 89 (2001). http://dx.doi.org/10.1016/S0308-8146(00)00214-4

9. Z. Gyori, and J. Prokisch, J. Agric. Food Chem. 47, 2751 (1999). http://dx.doi.org/10.1021/jf980781b

10. I. Al-Saleh and N. Shinwari, Biolog. Trace Element Res. 83, 91 (2001). http://dx.doi.org/10.1385/BTER:83:1:91

11. J. M. Llobet, G. Falcoa, C. Casas, A. Teixidoa, and J. L. Domingo, J. Agric. Food Chem. 51, 838 (2003). http://dx.doi.org/10.1021/jf020734q

12. United State Environmental Protection Agency (EPA) 816-F-09-004, (2009).http://water.epa.gov/drink/contaminants/upload/mcl-2.pdf

13. Codex Alimentarius Commission, Joint FAO/WHO Food Standards Programme, 31st session (Geneva, switzerland, 2008).

14. Codex Alimentarius Commission, Joint FAO/WHO Food Standards Programme, $5^{\text {th }}$ session (The Hague, The Netherlands, 2011).

15. Office of Drinking Water, Health Advisory-chromium (EPA, Washington, DC, US, 1987). 
16. RIWA, Composition of the Water of the Rhine in 1986 and 1987 (Amsterdam, 1989).

17. B. K.Handa, Adv. Environ. Sci. Technol. 20, 189 (1988).

18. W. Slooff, Integrated Criteria Document Chromium. Bilthoven (National Institute of Public Health and Environmental Protection, Neatherland, 1989) Report no. 758701002.

19. S. J. Deverel and S. P. Millard, Environ. Sci. Technol. 22, 697 (1988). http://dx.doi.org/10.1021/es00171a013

20. A. W. Fonds, A. J. V. Eshof, E. Smit, Water Quality in the Netherlands, (National Institute of Public Health and Environmental Protection, Bilthoven, Netherlands, 1987) Report No. 218108004.

21. J. C. Méranger, K. S. Subramanian, and C. Chalifoux, Environ. Sci. Technol. 1979, 13, 707. http://dx.doi.org/10.1021/es60154a009

22. J. A. Cocho, J. R. Cervilla, M. L. Goldar, and J. R. Fdez-Lorenzo, Biolog. Trace Element Res. 32(1-3), 105 (1992). http://dx.doi.org/10.1007/BF02784593

23. C. G. Elinder, L. Friberg, G. F. Nordberg, and V. B. Vouk, Handbook on the Toxicology of Metals, $2^{\text {nd }}$ edition (Amsterdam, Elsevier Science Publishers, 1986) pp. 664-679.

24. J. O. Nriagu, Zinc in the environment, Part I, Ecological cycling (John Wiley, New York, 1980).

25. L. Hiisvirta, Vatten 1986, 42, 201 (1986).

26. P. Lahermo, The Geochemical Atlas of Finland, Part 1, The Hydrogeochemical Mapping of Finnish Groundwater (Geological Survey of Finland, Espoo, Finland, 1990).

27. S. O. Knowles, N. D. Grace, T. W. Knight, W. C. McNab, and J. Lee, Anim. Feed Sci. Technol. 131, 154 (2006). http://dx.doi.org/10.1016/j.anifeedsci.2006.04.015

28. A. Pechova, L. Pavlata, R. Dvorak, and E. Lokajova, Acta Vet. Brno. 77, 523 (2008). http://dx.doi.org/10.2754/avb200877040523

29. R. L. Kincaid, J. D. Cronrath, J. Dairy Sci. 75, 481 (1992). http://dx.doi.org/10.3168/jds.S0022-0302(92)77784-4

30. F. V. Silva, G. S. Lopes, J. A. Nobrega, G. B. Souza, and A. R. A. Nogueira, Acta Pt B-Atom Spectr. 56, 1909 (2001). http://dx.doi.org/10.1016/S0584-8547(01)00313-5 